\title{
Pengaruh Pendekatan Pendidikan Matematika Realistik Berbasis Etnomatematika terhadap Komunikasi Matematis Siswa Sekolah Dasar
}

\author{
Suci Nooryanti ${ }^{1 \bowtie}$, Sri Utaminingsih ${ }^{2}$, dan Henry Suryo Bintoro ${ }^{3}$ \\ ${ }^{1,2}$ Prodi Pendidikan Guru Sekolah Dasar, Universitas Muria Kudus \\ ${ }^{3}$ Prodi Pendidikan Matematika, Universitas Muria Kudus
}

\begin{abstract}
Info Artikel Abstract
Sejarah Artikel:

Diterima 28 April 2020

Direvisi 14 Mei 2020

Disetujui 15 Mei 2020

Keywords: Realistic

Mathematics,

Ethnomatematics,

Mathematical

Communication.

Paper type:

Research paper

The purposive of this study are (1) the average mathematical communication abilities of students who have learned by applying the ethnomatemics-based Realistic Mathematics Education approach, (2) the mastery of learning mathematical communication abilities of students who are taught with the Mathematics-Based Realistic Mathematics approach. This type of research is quantitative with true experimental design research design using the form of Posttest Only Control. The sample uses a simple random sampling technique and is carried out in class V SD 5 Jepang as an experimental class and class V SD 1 Gulang as a control class. Data collection techniques are tests of students' mathematical communication abilities. Data analysis techniques in this study include normality test, homogeneity test, average difference test and learning completeness test. The results showed that (1) the average mathematical communication ability of the experimental class students was higher than the average mathematical communication ability of control class students with expository learning; (2) students' mathematical communication abilities with ethnomatemicsbased Realistic Mathematics Education approach achieve mastery learning.
\end{abstract}

\begin{abstract}
Abstrak
Tujuan penelitian ini adalah (1) rata-rata kemampuan komunikasi matematis siswa yang mendapat pembelajaran dengan menerapkan pendekatan Pendidikan Matematika Realistik berbasis etnomatematika lebih tinggi dari pembelajaran ekspositori, (2) ketuntasan belajar kemampuan komunikasi matematis siswa yang diajar dengan pendekatan Pendidikan Matematika Realistik berbasis etnomatematika di atas $75 \%$. Jenis penelitian ini kuantitatif dengan desain penelitian true eksperimental design menggunakan bentuk Posttest Only Control. Sampel menggunakan teknik simple random sampling dan dilaksanakan di kelas V SD 5 Jepang sebagai kelas eksperimen dan kelas V SD 1 Gulang sebagai kelas kontrol. Teknik pengumpulan data adalah tes kemampuan komunikasi matematis siswa. Teknik analisis data dalam penelitian ini meliputi uji normalitas, uji homogenitas, uji perbedaan rata-rata dan uji ketuntasan proporsi. Hasil penelitian menunjukkan bahwa (1) rata-rata kemampuan komunikasi matematis siswa kelas eksperimen lebih tinggi daripada rata-rata kemampuan komunikasi matematis siswa kelas kontrol dengan pembelajaran ekspositori; (2) kemampuan komunikasi matematis siswa dengan pendekatan Pendidikan Matematika Realistik berbasis etnomatematika mencapai ketuntasan belajar di atas $75 \%$.
\end{abstract}

(C) 2020 Universitas Muria Kudus

Alamat korespondensi:
Program Studi Pendidikan Matematika
Fakultas Keguruan dan Ilmu Pendidikan Universitas Muria Kudus
Kampus UMK Gondangmanis, Bae Kudus Gd. L. 1t I PO. BOX 53 Kudus
Tlp (0291) 438229 ex.147 Fax. (0291) 437198
E-mail: sucinooryanti26@gmail.com




\section{PENDAHULUAN}

Pendidikan merupakan suatu proses yang penting dalam kehidupan manusia untuk mempersiapkan dan melahirkan sumber daya manusia yang berkualitas. Perkembangan Ilmu Pengetahuan dan Teknologi (IPTEK) menyebabkan kompetensi yang diperlukan oleh setiap individu semakin meningkat. Terjadinya proses belajar matematika yang baik pula dan peserta didik dengan mudah mempelajari matematika selanjutnya serta dengan mudah pula mengaplikasikan ke situasi baru, yaitu dapat menselesaikan masalah baik dalam matematika itu sendiri maupun ilmu lainnya atau dalam kehidupan sehari-hari (Hudojo, 1988).

Praktik yang ditemukan dilapangan masih banyak guru yang menggunakan model pembelajaran ekspositori dengan menggunakan metode ceramah dan tanya jawab. Hal tersebut membuat siswa menjadi pasif, sehingga hasil belajar siswa rendah. Ulya (2017), bahwa pembelajaran matematika yang terjadi di lapangan belum mampu membuat peserta didik memahami dan mengaplikasikan konsep untuk memecahkan masalah dalam kehidupan sehari-hari. Aktivitas antar siswa dirasa kurang, sehingga perilaku terkait pengkomunikasikan gagasan atau ide pemikiran masih sangat kurang. Hal ini menjadi pendukung kurangnya kemampuan komunikasi siswa.

Secara umum komunikasi diartikan sebagai suatu cara untuk menyampaikan pesan ke penerima pesan untuk memberitahu, pendapat, atau perilaku baik secara lisan maupun tak langsung melalui media (Susanto, 2016). Pengertian komunikasi juga diungkapkan oleh Ansari (2016) bahwa komunikasi merupakan suatu proses dimana individu menyampaikan sesuatu secara verbal kepada orang lain dengan tujuan merubah tingkah laku pendengarnya. Adler dan Rodman dalam Iriantara (2013) mengungkapkan bahwa dalam komunikasi dapat ditemukan tiga karakteristik yaitu: (1) komunikasi itu manusiawi; (2) komunikasi merupakan proses; (3) komunikasi itu bersifat simbolik. Maka dapat disimpulkan bahwa komunikasi merupakan proses penyampaian pesan yang bertujuan memberikan informasi baik secara langsung maupun tidak langsung.

Komunikasi matematis memiliki tujuh indikator yang dikemukakan Lestari dan Yudhanegara (2015) meliputi: 1) menghubungkan benda nyata, gambar, dan diagram ke dalam ide matematika; 2)menjelaskan ide, situasi dan relasi matematika secara lisan atau tulisan, dengan benda nyata, gambar, grafik, dan aljabar; 3) menyatakan peristiwa sehari-hari dalam bahasa matematika; 4) mendengarkan, diskusi, dan menulis tentang matematika; 5) membaca dengan pemahaman suatu presentasi matematika tertulis; 6) menyusun pertanyaan matematika yang relevan dengan situasi masalah; 7) membuat konjektur, menyusun argumen, merumuskan definisi dan generalisasi.

Berdasarkan hasil wawancara mengenai pembelajaran matematika dengan guru kelas V SD 5 Jepang diperoleh keterangan bahwa siswa sulit menguasai pelajaran matematika, siwa tidak terbiasa menyelesaikan soal dengan runtut. Guru kelas sudah baik dalam mengajar di kelas, hanya saja jarang menggunakan media pembelajaran. Hal ini membuat siswa kesulitan dalam menerima pelajaran matematika di kelas. Kesulitan yang sering dialami siswa kelas $\mathrm{V}$ yaitu ketika menerima masalah matematika yang berhubungan dengan pengkonstruksian ke benda kongkrit yang berada di sekitar dan dijadikan masalah matematika. Ketika ada soal yang membutuhkan penalaran siswa sering kesulitan dalam mengkomunikasikan dalam bentuk matematika. Kemampuan komunikasi matematis siswa masih sangat rendah dalam pelajaran matematika.

Salah satu pendekatan dalam pembelajaran matematika yaitu Pendidikan Matematika Realistik (PMR). Pendekatan ini diketahui sebagai pendekatan yang telah berhasil di Belanda. Pendidikan realistik dimulai dari sesuatu yang riil sehingga siswa dapat terlibat dalam proses pembelajaran yang diharapkan dapat meningkatkan kemampuan komunikasi matematis siswa. Pendidikan Matematika Realistik (PMR) merupakan pendekatan pembelajaran yang menekankan pada kebermanaan ilmu pengetahuan (Wijaya). Traffers (1987, dalam Wijaya, 2012) merumuskan lima karakteristik Pendidikan Matematika Realistik, yaitu: (a) penguatan konsep; (b) penggunaan model untuk matematisasi progresif; (c) pemanfaatan hasil kontruksi siswa; (d) interaktivitas; dan (e) keterkaitan.

Perkembangan Ilmu Pendidikan dan Teknologi (IPTEK), menjadikan tingkat kesadaran terhadap budaya lokal masyarakat Indonesia semakin menurun. Kemajuan IPTEK yang selalu berkembang mengakibatkan modernisasi. Modernisasi menyebabkan berkurangnya penerapan dan pemahaman terhadap pentingnya nilai budaya dalam masyarakat. Kurangnya penyisipan dan pemahaman budaya dan tradisi lokal dalam pembelajaran di kelas akan menyebabkan siswa kurang menghargai budaya yang ada dan tumbuh di lingkungan sekitar. Etnomatematika yaitu pembelajaran matematika dengan mengaitkan suatu materi yang dipelajari 
dengan budaya lokal sehingga peserta didik lebih mudah memahami suatu materi karena berhubungan langsung dengan budayanya sendiri.

Pembelajaran berbasis etnomatematika mengutamakan budaya sebagai media bagi siswa dalam memahami pengetahuan pembelajaran matematika. Penerapan etnomatematika sebagai suatu pendekatan pembelajaran akan sangat memungkinkan suatu materi yang dipelajari terkait dengan budaya siswa itu sendiri, sehingga pemahaman suatu materi oleh siswa menjadi lebih mudah karena materi tersebut terkait langsung dengan budaya mereka yang merupakan aktivitas sehari-hari di lingkungannya. Hal ini sangat membantu guru dalam proses pembelajaran untuk memahami suatu materi.

Penelitian ini dilaksanakan di SD 5 Jepang Mejobo Kudus, hal tersebut dikarenakan hasil kemampuan komunikasi matematis di sekolah tersebut masih rendah atau masih sebagian besar di bawah KKM. Kecamatan Mejobo merupakan salah satu kecamatan di Kabupaten Kudus yang terkenal dengan hasil kerajinannya. Kerajinan yang dihasilkan yaitu kerajinan anyaman bambu. Anyaman bambu di produksi menjadi aneka ragam, seperti gebyok, besek, kipas dan aneka macam yang dikreasikan dari anyaman bambu. Dalam materi volume kubus dan balok, menggunakan pengetahuan siswa tentang besek bambu. Penerapan etnomatematika agar siswa lebih tertarik dalam megikuti pelajaran serta menumbuhkan sikap positif siswa terhadap budaya lokal.

Istilah etnomatematika berasal dari kata ethnomathematics, yang diperkenalkan oleh D'Ambrosio seorang matematikawan Brasil pada tahun 1977. D'Ambrosio (1985) menyatakan bahwa etnomatematika diartikan sebagai matematika yang dipraktekkan di antara kelompok budaya diidentifikasi seperti masyarakat nasional suku, kelompok buruh, anak-anak dari kelompok usia tertentu dan kelas professional. Etnomatematika mulai diintergrasikan ke dalam kurikulum matematika sekolah dengan asumsi awal untuk melestarikan nilai dari kebudayaan yang semakin hilang ditelan perkembangan zaman (Abi, 2016).

Pembelajaran berbasis etnomatematika sesuai diterapkan di kurikulum 2013, yang menonjolkan peningkatan kemampuan peserta didik terhadap budaya dan pembelajaran yang berpusat pada peserta didik bukan berpusat pada guru. Pendapat penerapan pada kurikulum juga diungkapkan Orton (2006) yang menyatakan kita juga tidak boleh mengabaikan fakta bahwa kurikulum bukan hanya daftar topik dan ide yang akan diajarkan, tetapi juga memasukkan metode pengajaran, tentang mana budaya yang berbeda cenderung memiliki pandangan yang sangat kuat, dan dalam hal ini kita bergerak ke dalam alam keyakinan dan nilai-nilai.

Penerapan pendekatan Pendidikan Matematika Realistik (PMR) berbasis etnomatematika dengan menjadikan contoh kongkrit anyaman bambu sebagai bahan rujukan dalam menyampaikan materi kubus dan balok pada pembuatan soal-soal komunikasi matematis kubus dan balok. Penelitian ini diawali dengan pemberian masalah matematika yang nantinya diterapkan melalui pendekatan pendidikan matematika realistik. Sedangkan masalah matematika yang diberikan berkaitan dengan kehidupan sehari-hari khususnya mengacu pada budaya setempat. Keterkaitan pengetahuan siswa tentang budaya setempat membantu penyelesaian masalah matematika yang diberikan.

\section{METODE PENELITIAN}

Penelitian ini menggunakan jenis penelitian kuantitatif dengan desain penelitian true eksperimental design menggunakan bentuk Posttest Only Control Group Design (Sugiono, 2018). Bentuk dari desain penelitian tersebut sebagai berikut.

Tabel 1. Desain penelitian Posttest Only Control Group Design

\begin{tabular}{lll}
\hline Kelas & Tahap Pelakuan & Test \\
\hline Eksperimen & $\mathrm{X}$ & $\mathrm{O}_{2}$ \\
\hline Kontrol & - & $\mathrm{O}_{4}$ \\
\hline
\end{tabular}

Keterangan:

$\mathrm{O}_{2}$ : Post-test untuk kelas eksperimen

$\mathrm{O}_{4}$ : Post-test untuk kelas kontrol

$\mathrm{X}$ : Pendekatan Pendidikan Matematika Realistik berbasis etnomatematika

Populasi dalam penelitian ini adalah seluruh SD di Kecamatan Mejobo. Pengambilan sample dengan teknik cluster random sampling dan diperoleh SD 5 Jepang dan SD 1 Gulang. Penelitian ini dilaksanakan pada kelas V di SD 5 Jepang dan SD 1 Gulang pada semester genap tahun ajaran 2018/2019. Jumlah siswa pada kelas V SD 5 Jepang berjumlah 40 siswa dan SD 1 Gulang berjumlah 34 siswa.Teknik pengumpulan data adalah tes kemampuan komunikasi matematis siswa. Teknik analisis data dalam penelitian ini meliputi uji normalitas, uji homogenitas, uji perbedaan rata-rata dan uji proporsi.

\section{HASIL DAN PEMBAHASAN}

Hasil penelitian yang dilakukan yaitu kemampuan komunikasi matematis dari dua kelas 
sampel. Kelas eksperimen yang menerapkan pendekatan Pendidikan Matematika Realistik berbasis etnomatematika dan kelas kontrol yang menggunakan pembelajaran ekspositori. Tes sebagai alat ukur dalam mengukur kemampuan komunikasi matematis siswa. Pemberian tes dilakukan setelah kelas eksperimen diberikan materi empat kali pertemuan. Kemampuan komunikasi matematis pada kelas eksperimen mempunyai rata-rata klasikal 82,35 , nilai maksimum 94 dan nilai minimum 66. Kelas kontrol mempunyai rata-rata klasikal 77,12 , nilai maksimum 90 dan nilai minimum 66 .

Hasil temuan yang pertama menunjukkan bahwa terdapat perbedaan rata-rata tes kemampuan komunikasi matematis siswa yang signifikan antara kelas V Sekolah Dasar yang menerima pendekatan Pendidikan Matematika Realistik berbasis etnomatematika dengan siswa yang menerima pembelajaran ekspositori.

Tabel 2. Hasil Uji Perbedaan Rata-Rata Data Akhir

\begin{tabular}{llll}
\hline Sampel & Variansi & $\boldsymbol{t}_{\text {hitung }}$ & $\boldsymbol{t}_{\text {tabel }}$ \\
& & & \\
\hline $\begin{array}{l}\text { Kelas } \\
\text { Eksperimen }\end{array}$ & 46,13 & \\
\hline $\begin{array}{l}\text { Kelas } \\
\text { Kontrol }\end{array}$ & 33,74 & 3,57 & 1,99 \\
\hline
\end{tabular}

Berdasarkan uji perbedaan rata-rata yang menggunakan uji $\mathrm{t}$ dua sampel independen mendapatkan hasil bahwa tes kemampuan komunikasi matematis pada siswa yang menerima pendekatan Pendidikan Matematika Realistik berbasis etnomatematika memiliki rata-rata lebih tinggi daripada pembelajaran ekspositori. Berdasarkan uji $\mathrm{t}$ dua sampel independen di dapatkan thitung $(3,57)$ lebih besar dari $t_{\text {tabel }}(1,99)$ maka $\mathrm{H}_{0}=$ ditolak, yang artinya terdapat perbedaan rata-rata tes kemampuan komunikasi matematis siswa yang signifikan antara dua kelas sampel yang diteliti.

Terdapatnya perbedaan antara kedua pembelajaran, yaitu pada pendekatan Pendidikan Matematika Realistik berbasis etnomatematika memberikan kesempatan ada siswa untuk lebih aktif dan komunikatif dalam materi volume kubus dan balok. Sedangkan, pada pembelajaran ekspositori siswa kurang aktif dan komunikatif karena didominasi dengan ceramah guru. Berdasarkan hasil tersebut maka membuktikan bahwa terdapat perbedaan komunikasi matematis antara siswa yang menerima pendekatan Pendidikan Matematika Realistik berbasis etnomatematika dengan siswa yang menerima pembelajaran ekspositori.
Hasil tujuan penelitian kedua menunjukkan dapat memenuhi ketuntasan minimum (KKM) secara individual maupun klasikal. Hal tersebut diketahui dari uji ketuntasan belajar. Uji ketuntasan belajar individual berdadarkan uji t satu pihak kanan di dapatkan $t_{\text {hitung }}(6,84)$ lebih besar dari $\mathrm{t}_{\text {tabel }}(2,02)$ maka $\mathrm{H}_{0}$ diterima, artinya rata-rata nilai tes kemampuan komunikasi matematis siswa yang memperoleh pendekatan Pendidikan Matematika Realistik berbasis etnomatematika mendapat ketuntasan minumum (KKM) yaitu 75 .

Tabel 3. Hasil uji ketuntasan individual data akhir kelas eksperimen

\begin{tabular}{llll}
\hline Sampel & $\boldsymbol{t}_{\text {hitung }}$ & $\boldsymbol{t}_{\text {tabel }}$ & Kesimpulan \\
\hline Kelas & 6,84 & 2,02 & $\mu_{0}>75$ \\
Eksperimen & & &
\end{tabular}

Sedangkan uji ketuntasan klasikal berdasarkan uji $\mathrm{Z}$ diperoleh $\mathrm{Z}_{\text {hitung }}(2,19)$ lebih besar dari $\mathrm{Z}_{\text {tabel }}(1,65) \quad \mathrm{H}_{0}$ diterima sehingga dapat disimpulkan bahwa nilai tes kemampuan komunikasi matematis siswa yang memperoleh pendekatan Pendidikan Matematika Realistik berbasis etnomatematika mendapat ditas KKM lebih dari 75\% ketuntasan klasikal.

Tabel 4. Hasil uji ketuntasan klasikal data akhir kelas eksperimen

\begin{tabular}{llll}
\hline Sampel & $Z_{\text {hitung }} \boldsymbol{Z}_{\text {tabel }}$ & Kesimpulan \\
& & \\
\hline $\begin{array}{l}\text { Kelas } \\
\text { Eksperimen }\end{array}$ & 2,19 & 1,65 & $\mu>75 \%$ \\
\hline
\end{tabular}

Implementasi pendekatan Pendidikan Matematika Realistik berbasis etnomatematika dalam penelitian ini sudah diterapkan dalam setiap pertemuan, yang di masukkan dalam pembelajaran matematika. Penelitian ini terlaksana empat kali pertemuan. Pembelajaran yang terlaksanakan sudah meliputi indikator pendekatan Pendidikan Matematika Realistik yaitu penggunaan konteks, penggunaan model untuk matematisasi progresif, pemanfaatan hasil kontruksi siswa, interaktivitas dan keterkaitan. Setiap pertemuan sudah mengandung unsur etnomatematika yang dikaitkan dengan hasil kerajinan bambu di daerah sekitar siswa. Pembelajaran yang berlangsung sangat inovatif dengan adanya benda konkrit yang ditunjukkan oleh peneliti saat pertemuan berlangsung.

Penelitian ini relevan dengan penelitian yang telah dilakukan oleh Zaini (2014) yang menunjukan bahwa 1) pembelajaran dengan 
pendekatan matematika realistik tidak efektif ditinjau dari kemampuan penalaran tetapi efektif ditinjau dari kemampuan komunikasi matematika; 2) pembelajaran matematika dengan pendekatan konvensional tidak efektif ditunjau dari kemampuan penalaran dan komunikasi matematik siswa; 3) pembelajaran pendekatan matematika realistik lebih baik dari pembelajaran konvensional ditinjau dari kemampuan penalaran dan komunikasi matematik siswa. Keterkaitan penelitian tersebut dengan penelitian ini yaitu menjelaskan kefektifan penggunaan pendekatan matematika realistik terhadap komunikasi matematika.

\section{SIMPULAN}

Berdasarkan hasil penelitian ini menunjukkan terdapat perbedaan rata-rata kemampuan komunikasi matematis siswa yang mendapat pembelajaran dengan menerapkan pendekatan Pendidikan Matematika Realistik berbasis etnomatematika lebih tinggi daripada rata-rata kemampuan komunikasi matematis siswa dengan pembelajaran langsung, ditemukan kemampuan komunikasi matematis siswa dengan pendekatan Pendidikan Matematika Realistik berbasis etnomatematika mencapai ketuntasan belajar individu maupun klasikal.

Saran yang di rekomendasikan yaitu guru mata pelajaran matematika Sekolah Dasar dapat menerapkan pendekatan Pendidikan Matematika Realistik berbasis etnomatematika untuk meningkatkan kemampuan komunikasi matematis yang lebih baik. Tidak hanya itu bagi Sekolah Dasar dapat menerapkan pendekatan Pendidikan Matematika Realistik berbasis etnomatematika dalam pembelajaran matematika, dan juga menerapkan metode pembelajaran lain yang lebih inovatif.

\section{DAFTAR PUSTAKA}

Abi, Alfonsa M. 2016. Integrasi Etnomatematika dalam Kurikulum Matematika Sekolah. JPMI: Jurnal Pendidikan Matematika Indonesia, 1 (1): 1-6.

Ansari, Bansu I. 2016. Komunikasi Matematik, Strategi Berfikir dan Manajemen Belajar: Konsep dan Aplikasi. Banda Aceh: PeNa.

D'Ambrosio, U. 1985. Ethnomathematics and Its Place in the History And Pedagogy of Mathematics. For the Learning of Mathematics, 5 (1): 44-48.

Hudojo, Herman. 1988. Mengajar Belajar Matematika. Jakarta: Departemen Pendidikan Dan Kebudayaan Direktorat Jendral Pendidikan Tinggi Proyek
Pengembangan Lembaga Pendidikan Tenaga Kependidikan.

Iriantara, Yosep dan Syaripudin, Usep. 2013. Komunikasi Pendidikan. Bandung: PT Remaja Rosdakarya.

Lestari, Kurnia Eka dan M. Ridwan Yudhanegara. 2015. Penelitian Pendidikan Matematika (Panduan Praktis Menyusun Skripsi, Tesis, dan Karya Ilmiah dengan Pendekatan Kuantitatif, Kualitatif, dan Kombinasi Disertai dengan Model Pembelajaran dan Kemampuan Matematis). Bandung: PT Refika Aditama.

Orton, Anthony. 2006. Learning Mathematics: Issues, theory and classroom practice 3rd Edition. New York: Continuum.

Sugiyono. 2018. Metode Penelitian Pendidikan (Pendekatan Kuantitatif, Kualitatif, dan $R \& D)$. Bandung: Alfabeta.

Susanto. Ahmad. 2016. Teori Belajar dan Pembelajaran di Sekolah Dasar. Jakarta: Prenada Media Group.

Ulya, Himmatul dan Rahayu, Ratri. 2017. Efektivitas Pembelajaran ProbingPrompting Berbasis Etnomatematika Terhadap Kemampuan Literasi Matematika. Edudikara: Jurnal Pendidikan dan Pembelajaran, 2 (4), 315-323.

Wijaya, Ariyadi. 2012. Pendidikan Matematika Reakistik: Suatu Alternatif Pendekatan Pembelajaran Matematika. Yogyakarta: Graha Ilmu.

Zaini, Ahmad dan Marsigit. 2014. Perbandingan Keefektifan Pembelajaran Matematika dengan Pendekatan Matematika Realistik dan Konvensional ditinjau dari Kemampuan Penalaran dan Komunikasi Matematika Siswa. Jurnal Riset Pendidikan Matematika, 1 (2). 